\title{
AN EPIDEMIOLOGIC STUDY OF LINEAR ENAMEL HYPOPLASIA OF DECIDUOUS ANTERIOR TEETH IN GUATEMALAN CHILDREN
}

\author{
P. F. INFANTE* and G. M. Gillespiet \\ *Center for Human Growth and Development, University of Michigan. $1111 \mathrm{E}$. Catherine St.. \\ Ann Arbor. Michigan 48104, $\nmid$ Department of Health Services. Pan American Health Organization. \\ Washington, D.C. 20037
}

\begin{abstract}
Summary - Although linear enamel hypoplasia is commonly seen in children of malnourished communities throughout the world, the aetiology is undetermined. This study attempted to explore the distribution of this enamel defect in 429 Guatemalan children (ages 6-83 months) from four rural villages. The prevalence ranged from 18 to 24 per cent in three villages to 62 per cent in the fourth. The prevalence did not increase with age, suggesting caries was not an aetiologic factor. Protein supplement made available to pregnant mothers and children did not appear to reduce the occurrence of the lesion in children. Relatively fewer children manifested the lesion when born in the latter part of the year. No sex differences were observed. Siblings of children with the lesion had a prevalence significantly greater than the total study population. suggesting that factors operating at the family level enhance the occurrence of the hypoplastic lesion in children.
\end{abstract}

\section{INTRODUCTION}

Linear enamel hypoplasia of the deciduous incisor teeth is commonly seen in children living in malnourished communities throughout the world. In many countries the prevalence is reported to be greater among children of the lower social class (Enwonwu, 1973; Jelliffe et al., 1961; MacGregor, 1964). Estimates of its prevalence have ranged from 14 to 85 per cent in the developing countries (Enwonwu, 1973; Jelliffe and Jelliffe, 1971; Jones, Larson and Prichard, 1930; Sweeney, Saffir and De Leon, 1971). Although the occurrence of this lesion is not readily apparent in children of the United States, it has been observed in Apache Indian children, who were living in conditions of poverty (Infante. 1974). This hypoplasia appears to be the result of an interference with normal ameloblastic activity during the appositional phase of enamel development, which in turn results in an area of arrested matrix formation (Mayer and Baume, 1966). Clinically, the lesion is characterized by a horizontal groove most frequently found on the labial surface of the deciduous maxillary incisors. It is located on the portion of those teeth that are formed in the neonatal period: the middle third of the maxillary central incisor crown and the incisal third of the lateral incisor crown (Mayer and Baume, 1966). After these teeth erupt into the oral cavity, the grooves may become discoloured with melanin-like deposits. Often they become "invaded" by dental caries, which produces a characteristic lesion known by a variety of names such as odontoclasia (Iones et al., 1930; Mayer and Baume, 1966), circular caries (Mayer and Baume, 1966; Toth and Szabo, 1953), crescent-shaped caries (Jelliffe and Jelliffe, 1971), or bar-type decay (Nicholls, Sinclair and
Jelliffe, 1961). These teeth then become reduced progressively to blackened stumps. Eventually. the entire crowns are destroyed (Sweeney et al., 1971) and chronic periapical abscess follows. On a world-wide basis, this enamel defect may be the most common lesion of the deciduous dentition (Sweeney and Guzman, 1966). Although it appears to be related to events associated with the perinatal period. the aetiology is undetermined. Thus. the following study was conducted to obtain further information on the prevalence and distribution of linear enamel hypoplasia in a specific Guatemalan population involving al larger number of subjects than previously reported.

\section{MATERIALS AND METHODS}

In July and August 1973, a dental epidemiologic study was conducted in four rural Guatemalan villages to assess dental caries status. The villages are participating in a study being conducted by the Institute of Nutrition of Central America and Panama related to nutritional supplementation and mental development and behaviour. Although the dental study was designed to obtain baseline data to be used in the future to assess the effect of protein and fluoride supplementation on dental caries, in view of the previously noted presence of linear enamel hypoplasia in Guatemalan populations, it was decided to include an assessment of this condition in the anterior teeth in conjunction with the evaluation of dental caries status. The villages, San Juan. Conacaste. Santo Domingo and Espiritu Santo are located in the Department of El Progreso. which lies approximately $40 \mathrm{~km}$ northeast of Guatemala City. Three are located at an altitude of 823 
$\mathrm{m}$. The fourth, Espiritu Santo, is located at $275 \mathrm{~m}$. The climate is hot and dry, with the hottest season in the period March -May. This is followed by the rainy season which ends in October-November. Throughout the year, however, there is little variation in temperature. The region is almost wholly agricultural. Racially, the people are a mixture of Hispanic and Amerindian stock. In general, they maintain a Latin culture and are rcferred to as Ladinos. They constitute a population with generally moderate malnutrition (Habicht et al., 1973). Studies have demonstrated no significant differences in the genetic make-up among the populations of the four villages.

Prior to the field portion of the survey, calibration procedures were carricd out. Four hundred and ninety-seven children between the ages of 6 months and $7 \mathrm{yr}$ were examined by one dentist (P.I.). This comprised approximately $75-80$ per cent of the total

Table 1. Prevalence of linear enamel hypoplasia of the deciduous dentition in children of four rural villages by age (sexes combined), Guatemala, 1973

\begin{tabular}{|c|c|c|c|c|c|c|c|}
\hline $\begin{array}{l}\text { Age } \\
\text { group } \\
(\mathrm{yr})\end{array}$ & $N$ & \multicolumn{2}{|c|}{ N.P.D.* Because of } & Questionable & $\begin{array}{c}\text { Adjusted } \\
\qquad N\end{array}$ & \multirow[t]{2}{*}{$\begin{array}{c}\text { Positive } \\
\text { hypoplasia }\end{array}$} & \multirow[t]{2}{*}{$\begin{array}{c}\text { Prev. of } \\
\text { hypoplasia } \\
(\% \text { of adj } N)\end{array}$} \\
\hline & & & & San Juan & & & \\
\hline 1 & 12 & 10 & 0 & 0 & 2 & 0 & $0 \cdot 0$ \\
\hline 1 & 26 & 3 & 0 & 0 & 23 & 5 & $21 \cdot 7$ \\
\hline 2 & 29 & 0 & 0 & 1 & 28 & 9 & $32 \cdot 1$ \\
\hline 3 & 27 & 0 & 4 & 0 & 23 & 0 & $0-0$ \\
\hline 4 & 19 & 0 & 1 & 1 & 17 & 6 & $35 \cdot 3$ \\
\hline 5 & 18 & 0 & 1 & 1 & 16 & 2 & $12 \cdot 5$ \\
\hline 6 & 18 & 1 & 1 & 0 & 16 & 8 & $50 \cdot 0$ \\
\hline Total & 149 & 14 & 7 & 3 & 125 & 30 & $24 \cdot 0$ \\
\hline \multicolumn{8}{|c|}{ Conacaste } \\
\hline 1 & 6 & 3 & 0 & 0 & 3 & 1 & $33 \cdot 3$ \\
\hline 1 & 31 & 1 & 0 & 0 & 30 & 5 & $16 \cdot 7$ \\
\hline 2 & 25 & 0 & 0 & 0 & 25 & 6 & $24 \cdot 0$ \\
\hline 3 & 32 & 0 & 1 & 1 & 30 & 6 & $20 \cdot 0$ \\
\hline 4 & 21 & 0 & 4 & 1 & 16 & 1 & $6 \cdot 2$ \\
\hline 5 & 23 & 0 & 1 & 1 & 21 & 5 & 23.8 \\
\hline 6 & 16 & 2 & 1 & 0 & 13 & 5 & $38 \cdot 5$ \\
\hline Total & 154 & 6 & 7 & 3 & 138 & 29 & $21 \cdot 0$ \\
\hline \multicolumn{8}{|c|}{ Santo Domingo } \\
\hline 1 & 6 & 4 & 0 & 0 & 2 & 2 & $100 \cdot 0$ \\
\hline 1 & 18 & 1 & 0 & 2 & 15 & 8 & $53 \cdot 3$ \\
\hline 2 & 21 & 0 & 0 & 2 & 19 & 14 & 73.7 \\
\hline 3 & 17 & 0 & 2 & 0 & 15 & 7 & $46 \cdot 7$ \\
\hline 4 & 24 & 0 & 2 & 0 & 22 & 16 & $72 \cdot 7$ \\
\hline 5 & 17 & 0 & 2 & 0 & 15 & 10 & $66 \cdot 7$ \\
\hline 6 & 22 & 1 & 2 & 3 & 16 & 7 & 43.8 \\
\hline Total & 125 & 6 & 8 & 7 & 104 & 64 & $61 \cdot 5$ \\
\hline \multicolumn{8}{|c|}{ Espiritu Santo } \\
\hline 1 & 4 & 4 & 0 & 0 & 0 & 0 & - \\
\hline 1 & 6 & 0 & 0 & 0 & 6 & 0 & 0.0 \\
\hline 2 & 11 & 0 & 0 & 0 & 11 & 4 & $36 \cdot 4$ \\
\hline 3 & 12 & 0 & 0 & 0 & 12 & 3 & $25 \cdot 0$ \\
\hline 4 & 10 & 0 & 1 & 1 & 8 & 1 & $12 \cdot 5$ \\
\hline 5 & 13 & 0 & 0 & 0 & 13 & 2 & $15 \cdot 4$ \\
\hline 6 & 13 & 0 & 1 & 0 & 12 & 1 & $8 \cdot 3$ \\
\hline Total & 69 & 4 & 2 & 1 & 62 & 11 & $17 \cdot 7$ \\
\hline $\begin{array}{l}\text { All } \\
\text { Vill. } \\
\text { Total }\end{array}$ & 497 & 30 & 24 & 14 & 429 & 134 & $31 \cdot 2$ \\
\hline
\end{tabular}

* N.P.D., Not possible to determine. 
number of children in this age range in the four villages. A mouth mirror and dental explorer were used. Examinces werc scatcd on a wooden chair or held by an adult under natural light. The findings were recorded by a trained assistant. During the examinations, the anterior teeth were scrubbed with gauze sponges to facilitate detecting the hypoplastic lesion. Children were categorized as: (1) positively having the lesion present; (2) positively not having the lesion present; (3) too carious to determine whether or not the lesion was present; (4) questionable. in which case presence or absence was difficult to judge; and (5) not possible to determine (N.P.D.) because the maxillary incisors had not erupted far enough for detection of the lesion or because the maxillary incisors had exfoliated. A total of 54 children fell into categories (3) and (5). and they were not included in the prevalence calculations. A total of 14 children fell into category (4). Including these questionables in the denominator would only have changed prevalence calculations by 1 per cent, therefore, they were eliminated so that comparisons could be made between children who were identified as positively having or not having the lesion present. Thus, 429 children remained for analyses.

\section{RESULTS AND DISCUSSION}

Of the 134 children positively identified as having had the lesion (Table 1), the usual occurrence was on the labial surface of the deciduous maxillary incisors. In some cases, the lesion could also be identified near the incisal tip of the labial surface of the maxillary canine. A few children manifested the lesion on the lingual surface of the mandibular incisors and still fewer exhibited a hypoplastic groove on the middle third of the lingual surface of the maxillary first deciduous molar, associated with hypoplasia of the anterior teeth.

\section{Prevalence hy sex}

Analyses involving data of White Mountain Apache Indian children (P. F. Infante, unpublished), suggested that the prevalence of linear enamel hypoplasia was greater in boys than in girls. At birth, boys in general weigh more, have more muscle mass, are developmentally behind and have less subcutaneous fat than girls. Thus, boys would be expected to have greater nutritional requirements and less caloric reserves than girls at birth. Because the lesion presumably occurs on the portion of the tooth crowns that are forming within the

Table 2. Prevalence of linear enamel hypoplasia of the deciduous dentition in all children by age, sex groups separate and combined, Guatemala, 1973

\begin{tabular}{|c|c|c|c|c|}
\hline $\begin{array}{l}\text { Age } \\
\text { group } \\
(\mathrm{yr})\end{array}$ & $\begin{array}{c}\text { Adjusted } \\
\qquad N\end{array}$ & $\begin{array}{l}\text { Number with } \\
\text { hypoplasia }\end{array}$ & $\begin{array}{c}\text { Prevalence } \\
\text { (\% hypo.) }\end{array}$ & $\begin{array}{c}\text { Two-year average } \\
\text { prevalence } \\
\left(0_{0} \text {, hypo.) }\right.\end{array}$ \\
\hline \multicolumn{5}{|c|}{ Boys } \\
\hline$\leq 1$ & 47 & 11 & $23 \cdot 4$ & \multirow{2}{*}{$31 \cdot 4$} \\
\hline 2 & 39 & 16 & $41 \cdot 0$ & \\
\hline 3 & 38 & 9 & 23.7 & \multirow{2}{*}{$25 \cdot 0$} \\
\hline 4 & 34 & 9 & $26 \cdot 5$ & \\
\hline 5 & 31 & 14 & $45 \cdot 2$ & \multirow{3}{*}{37.3} \\
\hline 6 & 28 & 8 & 28.6 & \\
\hline Subtotal & 217 & 67 & $30 \cdot 9$ & \\
\hline \multicolumn{5}{|c|}{ Girls } \\
\hline$\leq 1$ & 34 & 10 & $29 \cdot 4$ & \multirow{2}{*}{$34 \cdot 6$} \\
\hline 2 & 44 & 17 & $38 \cdot 6$ & \\
\hline 3 & 42 & 7 & 16.7 & \multirow{2}{*}{$31 \cdot 0$} \\
\hline 4 & 29 & 15 & $51 \cdot 7$ & \\
\hline 5 & 34 & 5 & 14.7 & \multirow{3}{*}{$28 \cdot 6$} \\
\hline 6 & 29 & 13 & $44 \cdot 8$ & \\
\hline Subtotal & 212 & 67 & $31 \cdot 6$ & \\
\hline & & Sexes combined & & \multirow{3}{*}{$32 \cdot 9$} \\
\hline$\leq 1$ & 81 & 21 & 25.9 & \\
\hline 2 & 83 & 33 & 39.8 & \\
\hline 3 & 80 & 16 & $20 \cdot 0$ & \multirow{2}{*}{$28 \cdot 0$} \\
\hline 4 & 63 & 24 & $38 \cdot 1$ & \\
\hline 5 & 65 & 19 & $29 \cdot 2$ & \multirow{3}{*}{$32 \cdot 8$} \\
\hline 6 & 57 & 21 & $36 \cdot 8$ & \\
\hline Total & 429 & 134 & 31.2 & \\
\hline
\end{tabular}


Table 3. Prevalence of linear enamel hypoplasia in younger siblings of children with the hypoplastic lesion in relation to total population prevalence (villages separate and combined), Guatemala, 1973

\begin{tabular}{|c|c|c|c|c|c|}
\hline Village & $\begin{array}{c}\text { Number } \\
\text { of } \\
\text { families }\end{array}$ & $\begin{array}{l}\text { Number } \\
\text { younger } \\
\text { siblings }\end{array}$ & $\begin{array}{c}\text { Number } \\
\text { with } \\
\text { hypoplasia }\end{array}$ & $\begin{array}{l}\text { Sibling } \\
\text { prevalence }\end{array}$ & $\begin{array}{c}\text { Total } \\
\text { prevalence }\end{array}$ \\
\hline \multicolumn{6}{|l|}{ San } \\
\hline Juan & 12 & 18 & 6 & $33 \cdot 3$ & $24 \cdot 0$ \\
\hline Conacaste & 16 & 20 & 6 & $30 \cdot 0$ & $21 \cdot 0$ \\
\hline \multicolumn{6}{|l|}{ Santo } \\
\hline Domingo & 17 & 23 & 16 & $69 \cdot 6$ & $61 \cdot 5$ \\
\hline \multicolumn{6}{|l|}{ Espiritu } \\
\hline Santo & 2 & 2 & 1 & $50 \cdot 0$ & $17 \cdot 7$ \\
\hline \multicolumn{6}{|l|}{ All } \\
\hline villages & 47 & 63 & 29 & $46 \cdot 0$ & $31 \cdot 2$ \\
\hline
\end{tabular}

first 2 months of postnatal development, a significantly greater prevalence in boys would be compatible with ia theory of nutritional association. The data in Table 2. however, show no differences by sex. With villages combined, the prevalence for boys and girls was 31 and
32 per cent. respectively. Intersex comparisons for individual villages also showed the prevalences to be similar. These observations are similar to those made by $\mathrm{A}$. E. Sweeney (personal communication) in his study of Guatemalan populations.

Table 4. Prevalence of linear enamel hypoplasia of the deciduous dentition by month of birth for all children and for children living in three villages where the village prevalence was approximately the same, Guatemala, 1973

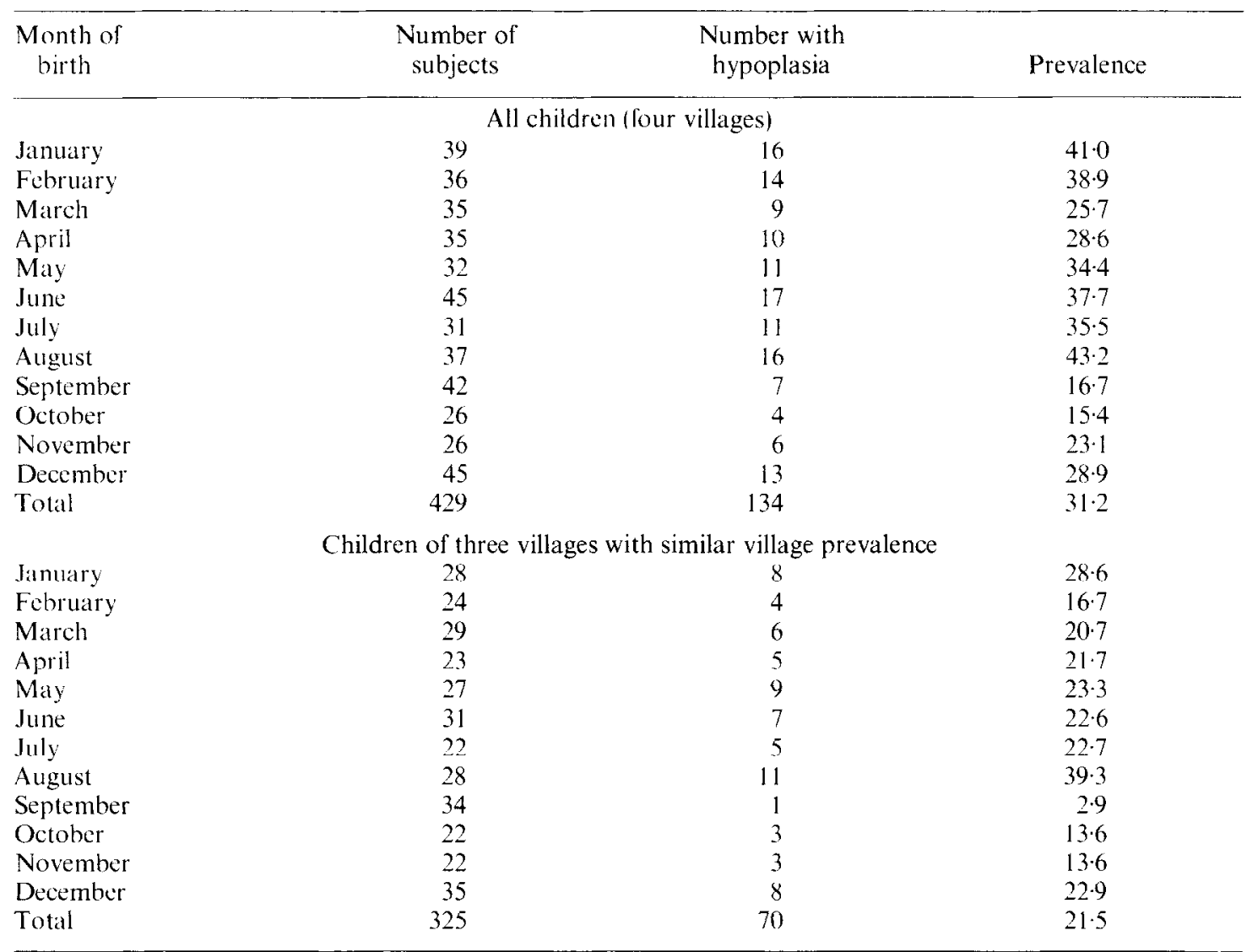


From the data in Table 1, one can observe that three villages had similar prevalences (18-24 per cent), while children of the fourth village, Santo Domingo, had a prevalence three times that of the other villages. The reason for the high prevalence in Santo Domingo is not known. The village did not appear to be significantly different from the other villages with regard to health care, nutritional or socio-economic status.

\section{Provalence by age}

A number of children who did not manifest linear hypoplasta exhibited a linear hypocalcified line on the maxillary deciduous anterior teeth in the same area where hypoplasia was seen in other children. In the latter condition, there was no discontinuity in the normal contour of the enamel surface and these children were classified as not having the lesion present. This observation does suggest the possibility that the hypocalcified line may be a mild expression of those factors, which in severe expression cause the hypoplastic defect. Since a microscopic neonatal line is found in all children's incisors, depending on the degree of stimulus. a variety of ameloblastic dysfunctions may occur which could result in a spectrum of defects ranging from the microscopic to the hypocalcified to the grossly hypoplastic defect.

To determine whether or not the enamel hypoplastic groove could possibly be the result of enamel decalcification from carious activity, the hypoplastic lesion was studied by age. If caries were an aetiologic factor, the previlence would have been expected to increase with agc. The data in Table 2 , however, show that the prevalence did not increase with age. With data for boys and girls combined. children of the two youngest age groupings had the same prevalence as children of the two oldest age groupings. Children of ages 3 and 4 years combined had a slightly lower prevalence. 28.(), than the extremes. These findings would support the hypothesis that the linear groove is not the result of carious activity, but rather a truly developmental defect.

In two of the study villages, San Juan and Conacaste, the mothers and children have had a protein supplement, Atole. available to them since 1970. If protein supplementation had any impact on the occurrence of the lesion in children, children of less than 36 months. on at group basis. would have heen expected to have a lower prevalence than the children of these villages who were older than 36 months. Combining the data for the younger-aged children of San Juan, Table 1, would show that 26 per cent of the children less than 36 months manifested the lesion compared to 22 per cent for children born prior to supplementation. A similar comparison for the children of Conacaste, Table 1, would show that both groups had a previlence of 21 per cent. Thus, on a group hasis, the protein supplement made available to pregnant mothers and children did not appear to reduce the occurrence of linear hypoplasia in children. Nevertheless, this finding does not necessarily rule out a nutritional association.
If mothers use the protein supplement as a substitute rather than a true supplement to their normal dicts. the mothers' nutritional status may remain unchanged even though they take the protein supplement. Further, infectious or metabolic disturbances may render adequate levels of ingested protein unutilized so that an adequate protein supplement may not necessarily result in adequate protein utilization at $\mathrm{lbe}$ cellulàr level.

\section{Prevalence in siblings of children with the lesen}

Sweeney and Guzman (1966) observed that multiple cases tended to occur in families. To corroborate their findings, the prevalence in the younger siblings of the children who exhibited the lesion was compared to the prevalence for the total population. Table 3 shows the siblings in each village to have had a prevalence greater than the total village prevalence. For all villages combined. 46 per cent of the younger siblings manifested the lesion compared to 31 per cent for the total population. Assuming that 31 per eent wals the true prevalence for the total population. the difference was significant at the 0.05 level of confidence. thus supporting the observations of Sweeney and Giuman. The 50 per cent increase in prevalence in siblings as compared to the general study population suggests that factors operating at the family level enhance the occurrence of the lesion in children.

\section{Prevalence by month of birth}

The distribution for the prevalence of the fesion bs month of birth for all children and for children of the villages where the village prevalenees were similar 118 24 per eent) can be seen in Table 4. These analyses show that the village with the highest prevalence did not obscure the general shape of the distribution. The data show that children born in August had the highest prevalence. whereas children born in the months of September, October and November hat the relatively lowest prevalence. The relatively low occurrence of the hypoplasia in children born in the latter part of the year would appear to merit further investigation and could possibly be related to dietary patterns or other environmental factors influencing the hahits of the village inhabitants.

The data of Scrimshaw. Taylor and Gordon (1968) show the incidence of weanling diarrhoea in Guatematlan children to be relatively lower in the latter part of the year. In the same study, they also show that. among wholly breast-fed children. about 18 per cent had acute diarrhoeal disease in the first 2 months of life. This is per cent is similar to the hypoplasia prevalences for three villages as shown in Table 3 (last column). As the source of the diarrhoea is thought to be spread by personal contact (Scrimshaw et al. 1968). and the ditit presented here suggest that factors operating at the family level enhance the occurrence of the hypoplastic lesion in children, and Sweeney "t chl. have demonstrated that the lesion was associated with infection in the first 35 days of life. factors associated with acute 
diarrhoea or the diarrhoeal disease itself might be further explored as a possible aetiologic agent, through more detailed observation at the individual child level. Likewise, further consideration might be given to the apparent higher prevalence in one village, to ascertain whether factors influencing this condition might be identified.

Acknowledgements-This paper is based on a report submitted to the National Institute of Dental Research by the Pan American Health Organization in fulfilment of contract No. PD-116285-3. The paper was prepared as a result of observations made on data collected in conjunction with a more comprehensive study conducted for the Pan American Health Organization and the Institute of Nutrition of Central America and Panama (INCAP). The collaboration of INCAP and in particular, the staff of the Division of Human Development is gratefully acknowledged. We also thank Dr. A. L. Russcll, Dr. S. M. Garn for their suggestions and B. H. Infante for her assistance in the field.

\section{REFERENCES}

Enwonwu C. O. 1973. Influence of socio-economic conditions on dental development in Nigerian children. Archs oral Biol. 18, 95-107.

Habicht J. P., Schwedes J. A., Arroyave G. and Klein R. E. 1973. Biochemical indicies of nutrition reflecting ingestion of a high protein supplement in rural Guatemalan children. Am. J. clin. Nutr. 26, 1046-1052.

Infante P. F. 1974. Enamel hypoplasia in Apache Indian children. Ecol. Food Nutr. 3, 155-156.
Jelliffe D. B., Jelliffe E. F. P., Garcia I and de Barrios G. 1961. The children of the San Blas Indians of Panama. $J$. Pediat. 59, 271-285.

Jelliffe D. B. and Jelliffe E. F. P. 1971. Linear enamel hypoplasia of deciduous incisor teeth in malnourished children. Am. J. clin. Nutr. 24, 893.

Jones M. R., Larson N. P. and Prichard G. P. 1930. Dental disease in Hawaii--I: Odontoclasia: a clinically unrecognized form of tooth decay in the pre-school child of Honolulu. Dent. Cosmos, 72, 439-450.

MacGregor A. B. 1964. The role of physical properties of food in dental caries. Bibl. Nutr. Dieta, 5, $119-142$.

Mayer J. and Baume L. J. 1966. Pathologie de la melanodontie infantile, de l'odontoclasie et de la carie circulaire. Rev. Suisse Odont. 76, 48-92.

Nicholls L., Sinclair H. M. and Jelliffe D. B. 1961. Tropical Nutrition and Dietetics, 4th edn, p. 159. Tindall \& Cox, London.

Scrimshaw N. S., Taylor C. E. and Gordon J. E. 1968. Interactions of nutrition and infection. W.H.O. Monogr. No. 57, Geneva, pp. 216-261.

Sweeney E. A. and Guzman M. 1966. Oral conditions in children from three highland villages in Guatemala. Archs oral Biol. 11, 687-698.

Sweeney E. A., Saffir A. J. and de Leon R. 1971. Linear hypoplasia of deciduous incisor teeth in malnourished children. Am. J. clin. Nutr. 24, 29-31.

Sweeney E. A.. Cabrera J., Urrutia J. and Mata L. 1969. Factors associated with linear hypoplasia of human deciduous incisors. $J$. dent. Res. 48, 1275-1279.

Toth K. and Szabo I. 1953. Dental conditions of preschool children (1-6 years of age) in Szeged, Hungary. $J$. dent. Res. 38, 451-463.

Résumé-Quoique l'hypoplasie de l'émail liniaire est rencontrée ordinairement chez les enfants dans les communautés sous-alimentées du monde entier, son étiologie est indéterminée. Cette étude a tâchée d'explorer la distribution de ce défaut de l'émail chez 429 enfants Guatémaltèques (âge 6-83 mois) de quatre villages ruraux. La fréquence variait de 18 à 24 pour cent dans trois villages jusqu'à 62 pour cent dans le quatrième. La fréquence n'augmentait pas avec l'âge, suggérant que les caries n'étaient pas un facteur étiologique. Les suppléments de protéines rendus disponibles aux mères enceintes et aux enfants ne paraissaient pas réduire l'occurrence de la lésion chez les enfants. Rélativement moins d'enfants nés dans la dernière partie de l'année présentaient cette lésion. On n'a pas observé des différences de sexe. Les enfants avec lésions, nés de même parents avaient une fréquence significativement plus grande que la population étudiée en totalité, suggérant que les facteurs agissant au niveau de la famille rehausse l'apparition des lésions hypoplasiques chez les enfants.

Zusammenfassung-Obwohl lineare Schmelzhypoplasie bei Kindern in unterernährten Gemeinschaften überall in der Welt gefunden wird, ist die Ätiologie unbestimmt. Diese Untersuchung versucht, die Verteilung des Schmelzschadens an 429 Kindern aus Guatemala, (im Alter von 6-83 Monaten), aus vier ländlichen Dörfern zu erforschen. Der Befall bewegte sich zwischen 18 und 24 Prozent in drei Dörfern auf 62 Prozent in dem vierten Dorf. Der Befall erhöhte sich nicht mit Alter und läßt darauf schließen, daß Karies keinen ätiologischen Faktor besaß. Proteinzusatz, der schwangeren Frauen und Kindern zugänglich gemacht wurde, schien das Vorkommen von Schaden in Kindern nicht zu reduzieren. Verhältnismäßig weniger Kinder brachten 
den Schaden zum Ausdruck, wenn sie in dem späteren Teil des Jahres geboren waren. Es wurden keine Unterschiede im Geschlecht festgestellt. Nackkommen von Kindern mit dem Schaden zeigten einen beträchtlich größeren Befall als die untersuchte Gesamtbevölkerung, was darauf schließen läßt Faktoren, die auf der Familienstufe wirken, das Vorkommen hypoplastischen Schadens in Kindern begünstigen. 